Article

\title{
Exploring Associations between Attitudes towards Climate Change and Motivational Human Values
}

\author{
Narcisa Maria Oliveira Carvalho Dias ${ }^{1}\left(\mathbb{D}\right.$, Diogo Guedes Vidal ${ }^{2, *} \mathbb{1}$,

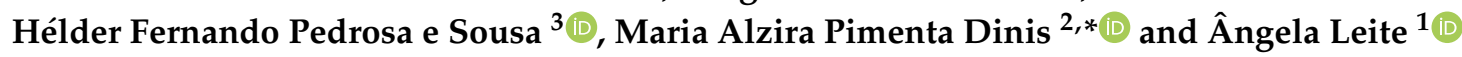 \\ 1 Faculty of Philosophy and Social Sciences, Portuguese Catholic University, Rua de Camões 60, \\ 4710-362 Braga, Portugal; 221914045@braga.ucp.pt (N.M.O.C.D.); aleite@ucp.pt (Â.L.) \\ 2 UFP Energy, Environment and Health Research Unit (FP-ENAS), University Fernando Pessoa (UFP), \\ Praça 9 de Abril 349, 4249-004 Porto, Portugal \\ 3 Department of Mathematics (DM.UTAD), University of Trás-os-Montes and Alto Douro, Quinta de Prados, \\ 5001-801 Vila Real, Portugal; hfps@utad.pt \\ * Correspondence: diogovidal@ufp.edu.pt (D.G.V.); madinis@ufp.edu.pt (M.A.P.D.)
}

Received: 6 October 2020; Accepted: 18 November 2020; Published: 19 November 2020

check for updates

\begin{abstract}
Climate change (CC) represents a global challenge for humanity. It is known that the impacts of anthropogenic actions are an unequivocal contribution to environmental issues aggravation. Human values are recognized as psychological constructs that guide people in their attitudes and actions in different areas of life, and the promotion of pro-environmental behaviors in the context of CC must be considered a priority. The present work aimed to understand the contribution of attitudes towards CC and selected sociodemographic variables to explain Schwartz's motivational human values. The sample consists of 1270 Portuguese answering the European social survey (ESS) Round 8. Benevolence and self-transcendence are the most prevalent human values among respondents. The majority believe in CC and less than half in its entirely anthropogenic nature. It was found that the concern with CC and education contributes to explain $11.8 \%$ of the conservation variance; gender and concern about CC explain 10.1\% of the variance of self-transcendence; and age, gender and concern about CC contribute to explain $13 \%$ of the variance of openness to change. This study underlines the main human values' drivers of attitudes towards CC, central components in designing an effective societal response to CC impacts, which must be oriented towards what matters to individuals and communities, at the risk of being ineffective.
\end{abstract}

Keywords: climate change (CC); pro-environmental behavior; European social survey (ESS); Portuguese population; Schwartz's human values

\section{Introduction}

Since the second half of the twentieth century, the world is experiencing a demographic transition, with the expectation that by 2050 the world population will be around nine billion human beings [1]. Issues related to global sustainability, utilization, sharing and scarcity of resources are thus raised $[2,3]$. Climate change (CC), recognized for its anthropogenic character, represents a concern at the worldwide level, and the international scientific community has proposed the term "Anthropocene" to characterize this new era of anthropic influence on Earth [4]. Policymakers seek to develop actions to mitigate CC impacts since, considered to be already irreversible [5]. As a result, the United Nations 2030 Agenda for Sustainable Development [6] presents a set of goals to be achieved, encompassed in objective 13, i.e., "Take urgent action to combat climate change and its impacts". Additionally, the World Health Organization [7] predicts that, between 2010 and 2050, CC may cause an additional 250,000 deaths each year due to malnutrition, malaria, diarrhea, pollution and excessive heat. It is expected that individuals 
or populations who do not believe that CC is a real problem, known as "climate deniers," or those who express low concern about CC, do not adopt behaviors contributing to mitigate CC impacts $[8,9]$. Science oriented towards environmental issues, namely on CC, has resorted to the concept of human values, understood by Rocheach [10] and Schwartz [11] as guidelines or criteria that people use to choose or justify actions or to assess people and events. These preceding cited authors consider values as central concepts, capable of unifying the interests of all sciences related to human behavior. Van der Linden [12] identifies gender, the political party, knowledge of the causes, impacts and responses to $\mathrm{CC}$, social norms, values, affection and personal experiences of extreme weather events, as significant predictors of risk perception in the face of CC. The study by van der Linden [12] also made it possible to identify two different dimensions in the perception of risk, namely personal and social risk.

Human values are assumed to be relatively stable dimensions of individuals' personalities and behaviors [13], but they can shift over during lifespan or by experiencing contact with different socio-cultural contexts. Values are generally considered to be indirectly related to pro-environmental behavior [14], and they play an important role in shaping beliefs and concerns about CC [15]. Just as values influence people's attitudes, choices and behaviors, particularly in the face of CC, it is possible that they also produce changes in the values that people subscribe to and by which they guide their lives. Although there is extensive literature on the impacts of the value towards CC, little is known about how these attitudes can influence human values. In the process of sustaining a concern, i.e., in this case, involving CC, human values change, and this can be of particular relevance, namely when studying the relationship between attitudes towards CC and human values.

Thus, this study aims to understand the contribution of attitudes towards CC to explain Schwartz's [11] values. For this purpose, an explanatory model of the second-order values of Schwartz [11], using selected sociodemographic variables and those related to CC, is identified in a representative sample of the Portuguese population.

\section{Theoretical Framework}

\subsection{Human Values}

The concept of basic human values was developed in the 1950s with the contribution of several authors, such as Schwartz [16]. Noting the absence of a comprehensive explanation and description of human values, a theory and a measuring instrument capable of representing the set of basic motivations relevant to the wide range of attitudes and behaviors observable in all areas of life, Schwartz chose to dedicate his work to human values and became widely known for his human values' theory and for the instrument that makes it possible to measure human values, i.e., the Schwartz value survey (SVS) [16-18]. The SVS, a 21-item questionnaire, is the most used instrument to date to study individual differences in human values [18]. SVS was found adequate to be applied in the present study as it presents high-reliability values.

For Schwartz [17], human values are beliefs, psychological constructs, i.e., a label for a cluster or domain of covarying behaviors, cognitive structures, linked to affection. They are oriented towards desirable objectives, going beyond specific situations or actions, and they serve as standards or criteria, being sortable by their relative importance. Human motivational values are conceptualized as relatively stable dimensions in each individual. Its origin has been consistently attributed to a combination of genetic contributions with exposure to multiple social contexts such as family, school, community and society in general. However, values can change in response to important socio-cultural changes [19] or extreme events [20]. Studying the role of attitudes towards CC in human values can help to prove that these values change due to these attitudes, with important consequences on environmental awareness. It is from the negotiation between competing values, in the face of an attitude or behavior, that a specific attitude or behavior is adopted, contributing each value to the action with two components: its importance for the action and its importance for the individual [17]. Schwartz's theory identifies ten basic personal values that are recognized in cross-cultural terms. The underlying idea is that values 
constitute a circular structure that reflects the motivation that each value expresses [21]. This structure reveals the compatibilities and conflicts between the ten values and appears to be culturally universal. Schwartz [21] also states that what distinguishes one value from another is the type of objective or motivation that it expresses, and what makes it likely to be universal is the fact that they all result from three basic human needs, i.e., individual needs such as biological organisms, needs resulting from social relationships and survival needs and well-being of the groups. According to Schwartz [16,21,22], the ten human motivational values are universalism, benevolence, conformity, tradition, security, power, achievement, hedonism, stimulation and self-direction. In addition to these ten human motivational values, Schwartz's theory $[11,21,22]$ explains the structure of the dynamic relationship between the values. At the origin of this organizational structure of values is the fact that actions that seek to achieve a certain value have consequences that conflict with some particular values and that are congruent with distinct ones. This organization allows the ten values to be arranged in a two-dimensional structure, composed of four fundamental orientations (second-order or higher-order values), positioned in two bipolar conceptual axes: one that opposes values of openness to change (hedonism, stimulation and self-direction) values to conservation (conformity, tradition and security) values and another that opposes self-transcendence (universalism, benevolence) values to self-promotion (power and achievement) values $[11,21,22]$.

Schwartz [16] observed that, throughout life, individuals are generally more socially involved, more faithful to behavior patterns and less exposed to great changes and challenges. Based on these assumptions, he then confirmed that age correlates more positively with the values of conservation (conformity, tradition and security) and more negatively with the values of openness to change (stimulation and self-direction) and hedonism. On the other hand, and over the years, people have reached a position of greater family and professional stability, tending to orient themselves more towards the well-being of others. Schwartz [16] confirmed that age correlates positively with values of self-transcendence (universalism and benevolence) and negatively with values of self-promotion (power and achievement). Psychoanalytic theories, cultural feminism and gender evolutionism, lead researchers studying values to postulate that men emphasize instrumental and action values, such as power, and women underline values more related to community expression, such as benevolence [23]. Schwartz [16] also confirmed that men emphasize more values of power and women more values of tradition.

In terms of education, and with greater and additional education, the openness to change, flexibility and breadth of perspective, essential to the values of self-promotion, will also presumably grow. Schwartz [16] confirmed these relationships, showing that the educational experience is central to the values of stimulation, reducing the values of tradition and conservation.

There is extensive interdisciplinary research that underlines the important contribution of human values to how individuals engage and relate to environmental issues. It is already well established that some values are favorable to the adoption of pro-environmental attitudes and behaviors $[8,13,24,25]$. The present work starts from the premise that the attitudes towards CC can have an impact on human values and, eventually, change them. Since this study aims to understand how attitudes towards CC explain human values, the Schwartz theoretical framework, recognized as a reliable worldwide framework, is considered to be useful for examining this relationship [26,27].

\subsection{Climate Change}

Knowledge about the anthropogenic nature of CC has evolved remarkably in recent decades [13], representing a priority in terms of international policy. The Intergovernmental Panel for CC [28] states, with $95 \%$ confidence that the global warming observed in recent decades is caused by anthropogenic action. In addition, the United Nations Framework Convention on Climate Change [29] acknowledges that CC is the result of human activity that, either directly or indirectly, alters the composition of the atmosphere. 
CC-related perceptions and beliefs are changing globally. Sudden events, such as floods or chronic ones, such as droughts, demonstrate that people are experiencing CC in the places where they live and work, and for this reason, phenomena never before experienced are increasingly occurring. This proximity to the consequences of CC increases the perception of risk, which results from its unpredictability, and represents an important stimulus for changing beliefs and attitudes [30,31]. On the other hand, CC's multifaceted character implies the need for an interdisciplinary look at CC, progressively understood as global changes, since its impacts go far beyond CC [32]. Examples include supply systems feeding with rising temperatures and extreme weather events [33]; the availability of water sources since defrosting prevents the natural course of water release when it is most needed, specifically in hot, dry summers and periods of drought [34,35]; public health issues with changes in climatic patterns that indirectly affect goods which are essential for human life, such as water, air quality, food, ecosystems, culminating in deaths, diseases and suffering, in addition to aggravating social inequalities, thus contributing for the increase of worldwide multi-vulnerabilities $[28,36]$.

\subsection{Relationship between Human Values and Attitudes towards Climate Change}

The first study that explicitly examined the relationship between values and beliefs about CC was aimed at predicting the acceptance of political measures to mitigate CC [37]. The same study found that the willingness to accept the proposed measures was positively related to self-transcendence values. The relationship between conservation and tradition values appears expressed in the literature related to attitudes towards CC in a less strong way.

The study by Corner et al. [13] reports an association between traditional values and skepticism towards CC. The same study points out the existence of a positive-weak relationship between traditional values and the support for political measures aimed at restricting the phenomenon. Corner and coauthors [13] noted the existence of certain types of values that are predictive of the positive involvement with environmental issues (self-transcendence and altruism), while other values have a less congruent and consistent relationship with positive long-term involvement (self-promotion). However, values are generally considered to be only indirectly related to pro-environmental behavior $[14,38]$. In particular, people who report higher values of self-transcendence tend to exhibit more pro-environmental behaviors [39], greater concern for environmental risks [40], more direct or indirect political involvement in environmental issues [41] and being positively involved with CC [13]. Poortinga and colleagues [8] point out that human values are important predictors of CC perceptions, along with sociodemographic factors such as age, gender and education.

Hornsey and colleagues [42] show that giving high importance to the natural environment is associated with believing that CC is real. On the other hand, the same authors concluded that the belief in CC has only a weak relationship with the extent to which people are willing to adopt climate-friendly behaviors. Social justice (concern for people) proved to be more motivating than biospheric values (concern for the environment) for the adoption of pro-environmental behaviors [42]. In their meta-analysis, the same authors conclude that the youngest, most educated and highest-earning people are those who are more likely to believe in CC.

In line with this thought, Howell [24] proposed the designation of "environmentally responsible behaviors" as an alternative expression to "pro-environmental behaviors", to capture other reasons for action, in addition to merely environmental ones. In the same study [24], it is observed that topics such as social justice, community, frugality and personal integrity appear as reasons for involvement in environmentally responsible actions, also suggesting the relevance of altruistic values as references for environmental action. Likewise, Howell e Allen [43] consider that it is not essential to subscribe to biospheric values for involvement in environmentally responsible actions and that, depending on the values that guide people's actions, aiming to mitigate CC, their behavior can be considered more pro-social than pro-environmental.

Chan [44] reveals that the values that favor the interest in the collective over the individual are more promoters of environmentally friendly behaviors. The same author also underlines that the 
personal values of self-transcendence and self-promotion will have less influence on the behavior of people in socio-cultural contexts that discourage individualism. Sloot and colleagues [45] highlight that the different behaviors aimed at producing pro-environmental social changes must be based on different values. The same authors note that public protests relate only to altruistic values (concern for others), while individual behaviors and actions based on community actions relate only to biospheric values (concern for the environment). Altruistic and biospheric values are part of the self-transcendence value class. Another line of research by Adger et al. [46] reveals that, just as values exert influence on how people view CC, it is possible that the latter also affects the personal and cultural values that people subscribe to. According to the same study, the cultural perspective helps to explain the differences in the responses of different populations to the same environmental risks. Thus, responses aimed at adapting or mitigating CC must be oriented towards what matters to individuals and communities, at the risk of being ineffective.

\section{Materials and Methods}

\subsection{Objectives}

The general objective of this study is to explore the contribution of attitudes towards CC to explain Schwartz's values [21], i.e., how these attitudes explain the variance of the author's motivational human values in a representative sample of the Portuguese population. Specific objectives include characterizing the sample; analyzing the association between the sample demographic characteristics and the variables associated with Schwartz's values [21]; and to identify an explanatory model of Schwartz's second-order values (conservation, self-transcendence, self-promotion and openness to change), using selected sociodemographic variables and variables related to CC.

Considering the literature and the objectives previously presented, the four following hypotheses were considered:

Hypothesis 1 (H1). Sociodemographic variables are correlated with Schwartz's values;

Hypothesis 2 (H2). Sociodemographic variables are correlated with variables about attitudes towards CC;

Hypothesis 3 (H3). People with greater concern in the face of CC and who most believe in the negative effects of these changes will subscribe to higher values of self-transcendence;

Hypothesis 4 (H4). Education, gender and age, as well as concern about CC, explain, respectively, conservation (education and concern for CC), self-transcendence (gender and concern for CC) and openness to change (age, gender and concern with CC).

\subsection{Study Design}

From a temporal perspective, the present research is transversal and has a descriptive-correlational design. The method underlying the conduct and operationalization of this research is of a quantitative type, aiming at the explanation, description and correlation of variables. The data were obtained from the European social survey (ESS), and a rigorous and standardized collection strategy, ensuring their validity and reliability, was performed. The ESS is a transnational survey of attitudes and behaviors that was established in 2001, and since then, it has been applied every two years. It is a survey that uses probabilistic cross-sectoral samples that are representative of the population aged 15 years or older, with residence in each country [47].

\subsection{Sample}

The sample of the present study was obtained from the Portuguese population surveyed in the ESS [48] in its 2016 edition and is described in Table 1. It is composed of 1270 participants, of whom the 
majority are female $(n=740,58.3 \%)$. The average age of the sample is 52.05 years $(S D=18.30 ; 15-93)$. Concerning the number of years of education, the average is 10.10 years $(S D=5.34 ; 0-25)$, with the majority being active from the labor point of view $(n=675,53.1 \%)$ : workers, students and housewives; and the remaining inactive $(n=595,46.9 \%)$ : unemployed, retired, sick and others. Most of the sample $(n=759,59.8 \%)$ has no children living at home. The majority of the participants $(n=785,61.8 \%)$ live in medium-sized cities and towns.

Table 1. Sociodemographic characteristics of the sample $(n=1270)$.

\begin{tabular}{ccccc}
\hline Variables & & $\boldsymbol{n}(\mathbf{\%}) / \mathbf{M} \pm S D$ & $S_{k w}$ & $K_{r t}$ \\
\hline Gender & Female & $\mathbf{7 4 0}(\mathbf{5 8 . 3 )}$ & & \\
& Male & $530(41.7)$ & & \\
Age & & $\mathbf{5 0 . 0 5} \pm 18.30$ & -0.109 & 0.231 \\
Education & Active & $\mathbf{1 0 . 1 0 \pm 5 . 3 4}$ & -0.942 & -0.753 \\
Work activity & Inactive & $575(\mathbf{5 3 . 1})$ & -0.126 & -1.987 \\
Feeling about & Allows living in comfort & $257(20.3)$ & 0.571 & -0.277 \\
income & Allows paying expenses & $\mathbf{6 4 7}(\mathbf{5 1 . 1})$ & & \\
& It is hard to live & $222(17.5)$ & & \\
& It is very difficult to live & $139(11)$ & & \\
& Does not respond & $5(0.4)$ & & \\
\hline
\end{tabular}

Note. $M=$ mean; $S D=$ standard deviation; $S_{k w}=$ skewness; $K_{r t}=$ kurtosis; bold—significant values.

Most of the sample ( $n=730,57.7 \%$ ) has the salary as the main source of income; the remainder $(n=537,42.3 \%)$ earns pensions, are beneficiaries of social transfers, has investments and others. Considering what people feel about their income, most $(n=647,51.1 \%)$ manages to reach the end of the month; 257 (20.3\%) participants claim to live comfortably with their income; the rest report having difficulties living with their current income.

\subsection{Procedures}

The present study did not require prior authorizations other than that of the Scientific Council of the Catholic University of Portugal, considering that it used a questionnaire and respective public database, which is freely available to the academic community. After outlining the topic to be studied, the variables that allowed to answer the research question were selected.

\subsection{Measures}

\subsubsection{European Social Survey (ESS)}

ESS is a transnational academic survey that measures the attitudes, beliefs and behavior patterns of different populations in more than thirty countries. Since 2002, ESS has been carried out every two years across Europe, and each round contains two modules of relevant social nature. The eighth round of ESS [48] includes a module on climate and another on energy; these data were used for the present study. ESS in Portugal is applied in the field, using the computer-assisted personal interviewing (CAPI) system of questionnaires on mobile computing devices. The ESS sample design in Portugal is a probabilistic design by stratified random sampling, excluding the Azores and Madeira archipelagos and locations with less than 10 houses. The samples are representative of all individuals who are at least 15 years of age or older and with no upper age limit and are residents of the country under study, Portugal in this specific case [48].

\subsubsection{Sociodemographic Items}

The information on the relationship between demographic variables and beliefs in CC and personal responsibility towards CC has been previously reported in the literature [13]. Even though human values are also not dissociated from sociodemographic issues, and therefore it seems appropriate to 
underline the relationship between the latter and attitudes towards CC. To characterize the sample, the information obtained through the application of the ESS in 2016 was considered to be significant for the present study: gender, age, education, work activity and feelings about income.

Gender is assessed on a nominal variable where answer 1 applies to men and 2 to women. The age variable, being a scalar variable, is represented by the number of complete years of age. The question "How many years of education have you finished?" also constitutes a scalar variable and is answered with a number that corresponds to the rounding of the integer number immediately afterward. The question "Which of the following situations apply better to what you did in the last 7 days?" is a variable of the nominal type whose response modalities have been dichotomized into "active", with category 1 corresponding to type 1 and "inactive" responses, corresponding to category 2, which started to aggregate all other response modalities.

The item "Which of the following descriptions is closest to what you feel about the current income of the people living in this house?", also of the nominal type, corresponds to responses between 1 and 5 , where 1 corresponds to "allows you to live in comfort"; 2 to "allows you to pay expenses"; 3 to "it is difficult to live", 4 to "it is very difficult to live" and 5 to "does not answer".

\subsubsection{Schwartz's Scale of Human Values}

The SVS was the first instrument developed to measure the ten human motivational values, according to Schwartz's theory $[17,21]$. To allow the measurement of the same basic values in a more specific and cognitively less complex way, the SVS was modified and reduced to a version with only 21 items (answered in about $10 \mathrm{~min}$ ), the portrait values scale (PVS) [21]. As a result, the new scale became accessible to populations with minimal education, and due to this modification, it was possible to integrate it into the EES [16]. Therefore, the PVS is an alternative scale to the SVS that was developed to be used in children from 11-years-old, the elderly and people with a low level of education, as well as to verify whether Schwartz's theory of values is valid, regardless of the instrument used [40]. In Portugal, the PVS is known as Schwartz's human values scale [18].

PVS includes descriptions of people referring to personal goals or desires that reflect the importance of a certain value (e.g., power value: "It is important for him to be rich. He wants to have many money and expensive things"). The description, always with two sentences, captures the values indirectly, unlike what happened with the original Schwartz's values scale [21]. For each pair of sentences, the respondent is asked to take a position on the extent to which that person can be compared to the respondent, on a six-point scale, where 1 corresponds to "exactly like me" and 6 to "has nothing to do with me".

The PVS consists of 21 items that are grouped into a trio and nine pairs that reflect ten motivational values: universalism (items 3, 8 and 19); benevolence (items 12 and 18); conformity (items 7 and 16); tradition (items 9 and 20); security (items 5 and 14); power (items 2 and 17); achievement (items 4 and 13); hedonism (items 10 and 21); Stimulation (items 6 and 15) and self-direction (items 1 and 11). In turn, these motivational values are grouped into four second-order dimensions: self-transcendence (universalism and benevolence); conservation (conformity, tradition and security); self-promotion (power and achievement) and openness to change (hedonism, stimulation and self-direction). These four dimensions are further organized into two bipolar axes, one that opposes self-transcendence and self-promotion values and another that opposes openness to change values to conservation values [16]. The score for each value is obtained by calculating the average of responses to the items that comprise it. The calculation of the value of the second-order dimensions also results from the average of the motivational values that constitute it.

According to Schwartz [49], and based on representative samples from 32 countries, more than 150,000 people have already responded to this scale, corroborating its cross-cultural validity. Its internal consistency is on average 0.56 , varying between 0.36 (tradition value) and 0.70 (achievement value). Considering the four second-order dimensions and using sample data from the United Kingdom and the Netherlands, Schwartz [16] presents values for internal consistency ranging from 0.74 for 
self-transcendence and 0.81 for self-promotion. In the Portuguese version of the scale, Granjo \& Peixoto [18] registered satisfactory reliability in a sample of 450 teachers, having obtained the following Cronbach's alpha values in the four dimensions of the scale: self-transcendence 0.80 ; conservation 0.73; self-promotion 0.73; openness to change 0.79 . In the same study, Schwartz's scale of values also revealed satisfactory indexes of factorial validity.

\subsubsection{Items Related to Attitudes to Climate Change}

Attitudes towards CC can be defined as cognitive representations that summarize people's assessment of CC. The relationship between attitudes and behavior cannot be only seen as straightforward once. In some cases, the predictive strength of attitudes depends on whether behavioral intentions or actual behaviors are the intended outcome [50,51]. In this specific study, this is not a concern, once the aim is to predict how these attitudes towards CC explain human values.

Six questions were used regarding the participants' attitudes towards CC using Likert-type response scales. The first question, "Do you think the global climate is changing?" intends to measure the tendency towards skepticism and the possible responses range from 1 (for sure, yes) to 4 (for sure, no). To the following question: "Do you think that climate change is caused by natural factors, human action or both?", the answers can be between 1 (exclusively natural factors) and 5 (exclusively human factors).

To the question "To what extent do you feel you have a personal responsibility to try to reduce climate change?", the answers can vary between zero (nothing) and 10 (a lot). To the following question: "To what extent are you concerned with climate change?", the answer can range from 1 (nothing) to 5 (extremely). In the question "To what extent do you think climate change will have a good or bad impact on people around the world?", the answers can range from zero (extremely bad) to 10 (extremely good). To the sixth and final question: "If many people around the world reduce their energy consumption, to what extent do you think it is likely to decrease climate change", it is possible to answer on a scale between zero (not likely) and 10 (extremely likely).

\subsection{Statistical Analysis}

The data related to the sample under study were analyzed using the statistical program Statistical Package for Social Sciences (SPSS), version 25. Descriptive (mean, standard deviation, minimum and maximum, skewness and kurtosis), reliability, mean comparisons (Student's $t$-test for independent samples), correlation (Pearson's $r$ and Spearman's $r h o$ ) and regression analyses (multiple linear regression (MLR)), were performed. The normality of the sample distribution was ensured by the values of skewness $\left(\left|S_{k w}\right|<3\right)$ and kurtosis $\left(\left|K_{r t}\right|<7\right)$ [52]. Parametric tests were used relating to the sample size. However, considering the ordinal nature of some variables, and despite the sample size, nonparametric tests were also applied [52].

The descriptive analysis was carried out to characterize the sample's sociodemography, attitudes towards CC and Schwartz's motivational and second-order values. The inferential analysis consisted of Pearson's and Spearman correlation coefficients determination for the sociodemographic variables, variables related to CC and motivational and second-order values. Inferential statistics also included the analysis of mean difference according to gender and also the MLR analysis to understand whether, and to what extent, the independent sociodemographic variables and CC variables explained the dependent variables that constitute Schwartz's second-order human values.

\section{Results}

The descriptive statistics of motivational values and second-order values are shown in Table 2. It is possible to observe that benevolence is the most reported value in the sample, translated by its lowest average. Power, on the contrary, is the value that is least reported in the responses of respondents, translated by the highest average recorded. Concerning the second-order values, self-transcendence is the dimension with the lowest average, the second-order value that is most reported in the sample. 
Some motivational and second-order values have very low internal consistency values. As verified by the authors of the Schwartz's scale, on average, in the samples of several studies, power is the item with the lowest value of Cronbach's alpha. However, benevolence has the highest value reported in this sample, while the authors of the scale registered the highest value in achievement. As for second-order values, self-transcendence has the highest Cronbach's alpha value (0.74) and self-promotion the lowest (0.54).

Table 2. Descriptive analysis of the motivational and second-order subscales.

\begin{tabular}{ccccccc}
\hline Subscales & $\boldsymbol{M}$ & $\boldsymbol{S D}$ & Minimum-Maximum & $\boldsymbol{S}_{\boldsymbol{k w}}$ & $\boldsymbol{K}_{\boldsymbol{r t}}$ & Cronbach's alpha \\
\hline Universalism & $\mathbf{2 . 3 2}$ & 0.76 & $1-5$ & -0.27 & -0.02 & 0.60 \\
Benevolence & $\mathbf{2 . 1 0}$ & 0.79 & $1-6$ & 0.43 & 0.37 & 0.69 \\
Conformity & 3.49 & 1.13 & $1-6$ & -0.20 & -0.37 & 0.51 \\
Tradition & 2.71 & 0.94 & $1-5.50$ & 0.07 & -0.36 & 0.38 \\
Security & 2.56 & 0.93 & $1-6$ & 0.31 & 0.05 & 0.55 \\
Power & $\mathbf{4 . 1 8}$ & 0.85 & $1-6$ & -0.25 & -0.09 & 0.25 \\
Achievement & 3.21 & 1.14 & $1-6$ & 0.12 & -0.50 & 0.67 \\
Hedonism & 2.85 & 1.04 & $1-6$ & 0.23 & -0.25 & 0.64 \\
Stimulation & $\mathbf{3 . 6 3}$ & 1.16 & $1-6$ & -0.31 & -0.39 & 0.60 \\
Self-direction & $\mathbf{2 . 4 2}$ & 0.90 & $1-6$ & 0.45 & 0.19 & 0.46 \\
Self-transcendence & $\mathbf{2 . 2 1}$ & 0.69 & $1-5.33$ & 0.19 & -0.12 & 0.74 \\
Conservation & 2.92 & 0.77 & $1-5.17$ & -0.11 & 0.01 & 0.65 \\
Self-promotion & $\mathbf{3 . 7 0}$ & 0.83 & $1.25-6$ & -0.01 & -0.22 & 0.54 \\
Openness to change & 3.00 & 0.81 & $1-5.50$ & -0.05 & -0.14 & 0.70
\end{tabular}

Note. $M=$ mean; $S D=$ standard deviation; $S_{k w}=$ skewness; $K_{r t}=$ kurtosis; bold- significant values.

The descriptive statistics of the items related to CC are presented in Table 3. It can be seen that the majority of the respondents $(77.3 \%)$ report that they are sure that the global climate is changing. Respecting the nature of the factors that contribute to CC, $43.1 \%$ of the respondents point to an equal contribution of natural and human factors. Of the remaining, $39.9 \%$ believe that CC is mainly due to human action.

About personal responsibility for trying to reduce CC, responses are widely distributed across all types of answers, with higher values to those that indicate greater personal responsibility. Regarding the concern with CC, $35 \%$ of the respondents say they are somewhat concerned, and $39.1 \%$ express much concern.

As for the good or bad impact that the CC may have, the responses are spread over all the possibilities of response, with greater frequency $(26.4 \%)$ concentrated on the "extremely bad" response. The majority of respondents expressed their belief that a reduction in energy consumption could contribute to reducing the CC impacts.

It should be noted that the item "Do you think that climate change is caused by natural factors, human action or both?" does not meet the normality criteria. 
Table 3. Descriptive analysis of items related to climate change $(n=1270)$.

\begin{tabular}{|c|c|c|c|c|c|c|c|c|c|c|c|c|c|c|c|}
\hline \multicolumn{16}{|c|}{ Variable } \\
\hline \multicolumn{16}{|c|}{ Variable 1: Do you think the global climate is changing? } \\
\hline \multirow[t]{2}{*}{$M \pm S D$} & $\begin{array}{l}\text { Min } \\
\operatorname{Max}\end{array}$ & $S_{k w}$ & $K_{r t}$ & \multicolumn{2}{|c|}{$\begin{array}{c}n \\
(\%)\end{array}$} & $\begin{array}{c}n \\
(\%)\end{array}$ & \multicolumn{2}{|c|}{$\begin{array}{c}n \\
(\%)\end{array}$} & \multicolumn{6}{|c|}{$\begin{array}{c}n \\
(\%)\end{array}$} & $\begin{array}{c}n \\
(\%)\end{array}$ \\
\hline & & & & \multicolumn{2}{|c|}{ Certainty yes (1) } & 2 & \multicolumn{2}{|c|}{3} & \multicolumn{6}{|c|}{ Certainty no (4) } & 0 \\
\hline $\begin{array}{c}1.25 \\
\pm .520\end{array}$ & $\begin{array}{l}1 \\
4\end{array}$ & 2.26 & 5.89 & \multicolumn{2}{|c|}{$\begin{array}{c}982 \\
(77.3)\end{array}$} & $\begin{array}{c}247 \\
(19.4)\end{array}$ & \multicolumn{2}{|c|}{$\begin{array}{c}23 \\
(1.8)\end{array}$} & \multicolumn{6}{|c|}{$\begin{array}{c}9 \\
(0.7)\end{array}$} & $\begin{array}{c}9 \\
(0.7)\end{array}$ \\
\hline \multicolumn{16}{|c|}{ Variable 2: Do you think that CC are caused by natural factors, human action or both? } \\
\hline$M \pm S D$ & $\begin{array}{l}\text { Min } \\
\text { Max }\end{array}$ & $s_{k w}$ & $K_{r t}$ & \multicolumn{2}{|c|}{$\begin{array}{l}\text { Natural factors only } \\
\text { (1) }\end{array}$} & 2 & 3 & 4 & \multicolumn{4}{|c|}{$\begin{array}{l}\text { Human factors only } \\
\text { (5) }\end{array}$} & \multicolumn{2}{|c|}{ No CC (55) } & 0 \\
\hline $\begin{array}{c}3.54 \\
\pm 1.66\end{array}$ & $\begin{array}{c}1 \\
55\end{array}$ & 24.09 & 747.84 & \multicolumn{2}{|c|}{$\begin{array}{c}21 \\
(1.7)\end{array}$} & $\begin{array}{c}55 \\
(4.3)\end{array}$ & $\begin{array}{c}548 \\
(43.1)\end{array}$ & $\begin{array}{c}507 \\
(39.9)\end{array}$ & \multicolumn{4}{|c|}{$\begin{array}{l}106 \\
(8.3)\end{array}$} & \multicolumn{2}{|r|}{$\begin{array}{c}1 \\
(0.1)\end{array}$} & $\begin{array}{c}32 \\
(2.5)\end{array}$ \\
\hline \multicolumn{16}{|c|}{ Variable 3: To what extent do you feel you have a personal responsibility to try to reduce CC? } \\
\hline$M \pm S D$ & $\begin{array}{l}\text { Min } \\
\operatorname{Max}\end{array}$ & $S_{k w}$ & $K_{r t}$ & $\begin{array}{l}\text { Nothing } \\
(0)\end{array}$ & 1 & 2 & 3 & 4 & 5 & 6 & 7 & 8 & 9 & $\begin{array}{l}\text { A lot } \\
(10)\end{array}$ & 0 \\
\hline $\begin{array}{c}5.70 \\
\pm 3.12\end{array}$ & $\begin{array}{c}0 \\
10\end{array}$ & -0.41 & -0.85 & $\begin{array}{c}140 \\
(11.0)\end{array}$ & $\begin{array}{c}30 \\
(2.4)\end{array}$ & $\begin{array}{c}62 \\
(4.9)\end{array}$ & $\begin{array}{c}66 \\
(5.2)\end{array}$ & $\begin{array}{c}66 \\
(5.2)\end{array}$ & $\begin{array}{c}186 \\
(14.6)\end{array}$ & $\begin{array}{c}122 \\
(9.6)\end{array}$ & $\begin{array}{c}136 \\
(10.7)\end{array}$ & $\begin{array}{c}163 \\
(12.8)\end{array}$ & $\begin{array}{c}90 \\
(7.1)\end{array}$ & $\begin{array}{c}163 \\
(12.8)\end{array}$ & $\begin{array}{c}46 \\
(3.6)\end{array}$ \\
\hline \multicolumn{16}{|c|}{ Variable 4: How concerned are you with CC? } \\
\hline$M \pm S D$ & $\begin{array}{l}\text { Min } \\
\operatorname{Max}\end{array}$ & $S_{k w}$ & $K_{r t}$ & \multicolumn{3}{|c|}{$\begin{array}{l}\text { Nothing } \\
\text { (1) }\end{array}$} & & & \multicolumn{3}{|c|}{3} & \multicolumn{2}{|l|}{4} & $\begin{array}{l}\text { Extremely } \\
\text { (5) }\end{array}$ & 0 \\
\hline $\begin{array}{c}3.5 \\
\pm .915 \\
\end{array}$ & $\begin{array}{l}1 \\
5\end{array}$ & -0.36 & -0.01 & \multicolumn{3}{|c|}{$\begin{array}{c}29 \\
(2.3)\end{array}$} & & & \multicolumn{2}{|c|}{$\begin{array}{l}444 \\
(35)\end{array}$} & \multicolumn{2}{|r|}{$\begin{array}{c}496 \\
(39.1) \\
\end{array}$} & & $\begin{array}{c}155 \\
(12.2)\end{array}$ & $\begin{array}{c}12 \\
(1.7)\end{array}$ \\
\hline \multicolumn{16}{|c|}{ Variable 5: To what extent do you think CC will have a good or bad impact on people around the world? } \\
\hline$M \pm S D$ & $\begin{array}{l}\text { Min } \\
\operatorname{Max}\end{array}$ & $S_{k w}$ & $K_{r t}$ & $\begin{array}{l}\text { Extremely } \\
\text { bad } \\
(0)\end{array}$ & 1 & 2 & 3 & 4 & 5 & 6 & 7 & 8 & 9 & $\begin{array}{l}\text { Extremely } \\
\text { good } \\
(10)\end{array}$ & 0 \\
\hline $\begin{array}{c}2.42 \\
\pm 2.26\end{array}$ & $\begin{array}{c}0 \\
10\end{array}$ & 0.97 & 0.71 & $\begin{array}{c}335 \\
\mathbf{( 2 6 . 4 )}\end{array}$ & $\begin{array}{c}149 \\
(11.7)\end{array}$ & $\begin{array}{c}201 \\
(16.1)\end{array}$ & $\begin{array}{c}218 \\
\mathbf{( 1 7 . 2 )}\end{array}$ & $\begin{array}{c}95 \\
(7.5)\end{array}$ & $\begin{array}{l}113 \\
(8.9)\end{array}$ & $\begin{array}{c}38 \\
(3.0)\end{array}$ & $\begin{array}{l}26 \\
(2)\end{array}$ & $\begin{array}{c}21 \\
(1.7)\end{array}$ & $\begin{array}{c}10 \\
(0.8)\end{array}$ & $\begin{array}{l}13 \\
(1)\end{array}$ & $\begin{array}{c}48 \\
(3.8)\end{array}$ \\
\hline \multicolumn{16}{|c|}{ Variable 6: If many people around the world reduce their energy consumption, to what extent do you think it is likely to decrease CC? } \\
\hline$M \pm S D$ & $\begin{array}{l}\text { Min } \\
\operatorname{Max}\end{array}$ & $S_{k w}$ & $K_{r t}$ & $\begin{array}{l}\text { Not } \\
\text { likely } \\
(0) \\
\end{array}$ & 1 & 2 & 3 & 4 & 5 & 6 & 7 & 8 & 9 & $\begin{array}{l}\text { Extremely } \\
\text { likely } \\
\text { (10) }\end{array}$ & 0 \\
\hline $\begin{array}{c}6.45 \\
\pm 2.52\end{array}$ & $\begin{array}{c}0 \\
10\end{array}$ & -0.66 & 0.07 & $\begin{array}{c}46 \\
(3.6)\end{array}$ & $\begin{array}{l}13 \\
(1)\end{array}$ & $\begin{array}{c}39 \\
(3.1)\end{array}$ & $\begin{array}{c}56 \\
(4.4)\end{array}$ & $\begin{array}{c}54 \\
(4.3)\end{array}$ & $\begin{array}{c}176 \\
(13.9)\end{array}$ & $\begin{array}{l}153 \\
(12)\end{array}$ & $\begin{array}{c}202 \\
(15.9)\end{array}$ & $\begin{array}{c}202 \\
(15.9)\end{array}$ & $\begin{array}{c}87 \\
(6.9)\end{array}$ & $\begin{array}{l}153 \\
(12)\end{array}$ & $\begin{array}{l}89 \\
(7)\end{array}$ \\
\hline
\end{tabular}

Note. $M=$ mean; $S D=$ standard deviation; $M i n=$ minimum; $M a x=$ maximum; $S_{k w}=$ Skewness; $K_{r t}=$ kurtosis; $C C$ = climate change; bold—significant values. 
To answer to $\boldsymbol{H} \mathbf{1}$ (sociodemographic variables are correlated with Schwartz's values), the Spearman correlation coefficient was calculated (Table 4). In the correlation between the dimensions of the Schwartz's scale of values (first and second-order) and the sociodemographic variables, it is possible to verify that, with the second-order variables, conservation is statistically negatively correlated with age $(r=-0.220)$ and work activity $\left(r_{s}=-0.220\right)$ and positively correlated with education $(r=0.322)$. Thus, conservation is higher in respondents of older age and also higher in inactive ones, compared to active workers, in terms of work, being lower when education is higher, thus partially confirming $\mathbf{H 1}$. On the contrary, openness to change correlates positively with age $(r=0.342)$ and work activity $\left(r_{s}=0.210\right)$ and correlates negatively with education $(r=-0.253)$, confirming H1. In this case, older and inactive respondents show less openness to change, and those with more education express greater openness to change.

Table 4. Correlation coefficients between motivational and second-order values and sociodemographic variables.

\begin{tabular}{|c|c|c|c|c|c|}
\hline Subscales & Gender $^{(1)}$ & Age & Education & Work $^{(2)}$ & Feeling About Income (3) \\
\hline Benevolence & $-0.155 * *$ & 0.036 & -0.066 & -0.019 & 0.020 \\
\hline Tradition & -0.042 & $-0.185^{* *}$ & $0.273^{* *}$ & $-0.175^{* *}$ & $-0.130 * *$ \\
\hline Security & $-111^{* *}$ & $-0.107^{* *}$ & $0.152 * *$ & $-0.125^{* *}$ & $-0.074 * *$ \\
\hline Power & 0.014 & 0.020 & $0.092 * *$ & -0.023 & -0.046 \\
\hline Hedonism & $0.072 *$ & $0.301 * *$ & $-0.180^{* *}$ & $0.199 * *$ & $0.113^{* *}$ \\
\hline Stimulation & $0.094 * *$ & $0.324 * *$ & $-0.211 * *$ & $0.157 * *$ & $0.099 * *$ \\
\hline Self-direction & -0.035 & $0.145^{* *}$ & $-0.192 * *$ & $0.121 * *$ & $0.101 * *$ \\
\hline Self-transcendence & $-0.120 * *$ & 0.044 & $-0.099 * *$ & 0.012 & 0.045 \\
\hline Conservation & $-0.061 *$ & $-0.220 * *$ & $0.322 * *$ & $-0.220 * *$ & $-0.172^{* *}$ \\
\hline
\end{tabular}

Note. ${ }^{(1)}$ coding: 1 (male), 2 (female), ${ }^{(2)}$ coding: 1 (active), 2 (inactive); ${ }^{(3)}$ coding: from 1 (living in comfort) to 4 (very difficult to live). ${ }^{*} p<0.05,{ }^{* *} p<0.01$; bold—significant values.

In terms of the first-order variables, conformity correlates statistically negatively with age $(r=-0.205)$ and correlates positively with the number of years of education $(r=0.300)$. These results mean that the older respondents have higher conformity values since lower value responses reflect the greater agreement. Similarly, respondents with more years of education show less conformity. Tradition is also significantly positively correlated with education $(r=0.273)$, i.e., the higher the education, the lower the tradition value is reported. Achievement is positively correlated with age $(r=0.210)$. Thus, the older the respondents, the lower the achievement value. Hedonism and stimulation are significantly positively correlated with age $(r=0.311 ; r=0.324)$, translating that respondents of higher ages show lower results in these dimensions. In addition, stimulation is negatively correlated with education $(r=-0.211)$, meaning that higher education corresponds to greater stimulation (Table 4).

Table 5 shows the existence of statistically differences in relation to second-order values between men and women: women are more conservative $\left[t_{(1238)}=2.212, p=0.027\right]$ and self-transcending $\left[t_{(1247)}=4.668, p<0.001\right]$ than men and they are more open to change than women $\left[t_{(1202.865)}=-2.585\right.$, $p=0.010]$, confirming H1. 
Table 5. Differences concerning the averages of the first and second-order values.

\begin{tabular}{|c|c|c|c|c|c|c|c|c|c|c|c|c|}
\hline \multirow{3}{*}{ Subscales } & \multirow{3}{*}{ Gender } & \multirow{3}{*}{$M$} & \multicolumn{4}{|c|}{$\begin{array}{l}\text { Levene's Test for } \\
\text { Equality of } \\
\text { Variances }\end{array}$} & \multirow{3}{*}{$d f$} & \multicolumn{3}{|c|}{$t$-Test for Equality of Means } & & \\
\hline & & & $D P$ & $Z$ & Sig. & $t$ & & Sig. & $\begin{array}{c}\text { Mean } \\
\text { differen }\end{array}$ & Standard error & \multicolumn{2}{|c|}{$\begin{array}{l}95 \% \text { Confidence Interval of } \\
\text { the Difference }\end{array}$} \\
\hline & & & Di & 2 & & t & & (2 tails) & difference & of the difference & Lower & Upper \\
\hline \multirow{2}{*}{ Universalism } & $\mathrm{M}$ & 2.38 & 0.76 & \multirow{2}{*}{0.066} & \multirow{2}{*}{0.797} & 2.340 & 1247 & 0.019 & 0.10142 & 0.043 & 0.01640 & 0.18645 \\
\hline & $\mathrm{F}$ & 2.28 & 0.75 & & & 2.335 & 1120,636 & 0.020 & 0.10142 & 0.043 & 0.01621 & 0.18663 \\
\hline \multirow{2}{*}{ Benevolence } & $\mathrm{M}$ & 2.25 & 0.80 & \multirow[b]{2}{*}{3.459} & \multirow[b]{2}{*}{0.063} & 5.821 & 1260 & 0.000 & 0.25924 & 0.045 & 0.17186 & 0.34661 \\
\hline & $\mathrm{F}$ & 1.99 & 0.76 & & & 5.772 & 1099,683 & 0.000 & 0.25924 & 0.045 & 0.17111 & 0.34736 \\
\hline \multirow{2}{*}{ Conformity } & M & 3.48 & 1.08 & \multirow[b]{2}{*}{2.862} & \multirow[b]{2}{*}{0.091} & -0.253 & 1255 & 0.800 & -0.01629 & 0.064 & -0.14256 & 0.10998 \\
\hline & $\mathrm{F}$ & 3.49 & 1.16 & & & -0.256 & 1178,221 & 0.798 & -0.01629 & 0.064 & -0.14118 & 0.10860 \\
\hline \multirow{2}{*}{ Tradition } & $\mathrm{M}$ & 2.75 & 0.95 & \multirow{2}{*}{0.179} & \multirow{2}{*}{0.672} & 1.184 & 1260 & 0.237 & 0.06331 & 0.053 & -0.04162 & 0.16823 \\
\hline & $\mathrm{F}$ & 2.69 & 0.93 & & & 1.181 & 1127,104 & 0.238 & 0.06331 & 0.054 & -0.04190 & 0.16851 \\
\hline \multirow{2}{*}{ Security } & $\mathrm{M}$ & 2.70 & 0.99 & \multirow{2}{*}{6.667} & \multirow{2}{*}{0.010} & 4.460 & 1244 & 0.000 & 0.23730 & 0.053 & 0.13293 & 0.34167 \\
\hline & $\mathrm{F}$ & 2.46 & 0.88 & & & 4.384 & 1056,900 & 0.000 & 0.23730 & 0.054 & 0.13109 & 0.34351 \\
\hline \multirow{2}{*}{ Power } & M & 4.16 & 0.87 & \multirow{2}{*}{0.176} & \multirow{2}{*}{0.675} & -0.830 & 1255 & 0.407 & -0.04045 & 0.049 & -0.13602 & 0.05513 \\
\hline & $\mathrm{F}$ & 4.20 & 0.84 & & & -0.826 & 1110,523 & 0.409 & -0.04045 & 0.049 & -0.13651 & 0.05561 \\
\hline \multirow[b]{2}{*}{ Achievement } & M & 3.19 & 1.09 & \multirow[b]{2}{*}{3.008} & & -0.744 & 1249 & 0.457 & -0.04842 & 0.065 & -0.17617 & 0.07933 \\
\hline & $\mathrm{F}$ & 3.23 & 1.17 & & 0.083 & -0.751 & 1170,806 & 0.453 & -0.04842 & 0.064 & -0.17495 & 0.07812 \\
\hline & $\mathrm{M}$ & 2.75 & 0.96 & & & -3.153 & 1251 & 0.002 & -0.18652 & 0.059 & -0.30256 & -0.07047 \\
\hline Hedonism & $\mathrm{F}$ & 2.93 & 1.08 & 5.424 & 0.020 & -3.213 & 1201,408 & 0.001 & -0.18652 & 0.058 & -0.30041 & -0.07263 \\
\hline & M & 3.51 & 1.11 & & & -3.271 & 1247 & 0.001 & -0.21609 & 0.066 & -0.34569 & -0.08650 \\
\hline Stımulation & $\mathrm{F}$ & 3.72 & 1.18 & 4.151 & 0.042 & -3.306 & 1173,997 & 0.001 & -0.21609 & 0.065 & -0.34434 & -0.08785 \\
\hline & M & 2.44 & 0.84 & & & 0.748 & 1257 & 0.454 & 0.03857 & 0.052 & -0.06254 & 0.13969 \\
\hline Self-direction & $\mathrm{F}$ & 2.40 & 0.95 & 9.450 & 0.002 & 0.763 & 1204,597 & 0.446 & 0.03857 & 0.050 & -0.06064 & 0.13779 \\
\hline & M & 2.31 & 0.70 & & & 4.668 & 1246 & 0.000 & 0.18197 & 0.039 & 0.10549 & 0.25844 \\
\hline Selt-transcendence & $\mathrm{F}$ & 2.13 & 0.67 & 0.000 & 0.989 & 4.639 & 1103,261 & 0.000 & 0.18197 & 0.039 & 0.10501 & 0.25893 \\
\hline & M & 2.98 & 0.78 & & & 2.212 & 1238 & 0.027 & 0.09765 & 0.044 & 0.01105 & 0.18425 \\
\hline Conservation & $\mathrm{F}$ & 2.88 & 0.76 & 0.042 & 0.838 & 2.200 & 1107,690 & 0.028 & 0.09765 & 0.044 & 0.01056 & 0.18474 \\
\hline & $\mathrm{M}$ & 3.67 & 0.83 & & & -0.959 & 1244 & 0.338 & -0.04581 & 0.048 & -0.13955 & 0.04794 \\
\hline Self-promotion & $\mathrm{F}$ & 3.72 & 0.83 & 0.100 & 0.752 & -0.959 & 1132,227 & 0.338 & -0.04581 & 0.048 & -0.13949 & 0.04788 \\
\hline Openness to & M & 2.90 & 0.75 & & & -2.533 & 1242 & 0.011 & -0.11853 & 0.047 & -0.21032 & -0.02673 \\
\hline Change & $\mathrm{F}$ & 3.02 & 0.86 & 11.319 & 0.001 & -2.585 & 1202,865 & 0.010 & -0.11853 & 0.046 & -0.20848 & -0.02857 \\
\hline
\end{tabular}

Note. $M$ = Mean; $S D$ = standard deviation; $Z$ = z score; Sig = significance; $t$ = Student's $t$-test; $d f$ = degrees of freedom; bold—significant values. 
To respond to $\mathbf{H} \mathbf{2}$ (sociodemographic variables are correlated with variables about attitudes towards (C), it is possible to see in the correlation between the variables related to CC and the sociodemographic variables, presented in Table 6, that the feeling of personal responsibility to reduce CC significantly correlates, negatively with age $\left(r_{s}=-0.203\right)$ and feeling towards income $\left(r_{s}=-0.195\right)$ and positively with education $\left(r_{s}=0.305\right)$, thus confirming $\boldsymbol{H} 2$.

Table 6. Spearman Rho correlation coefficients between variables related to climate change and sociodemographic variables.

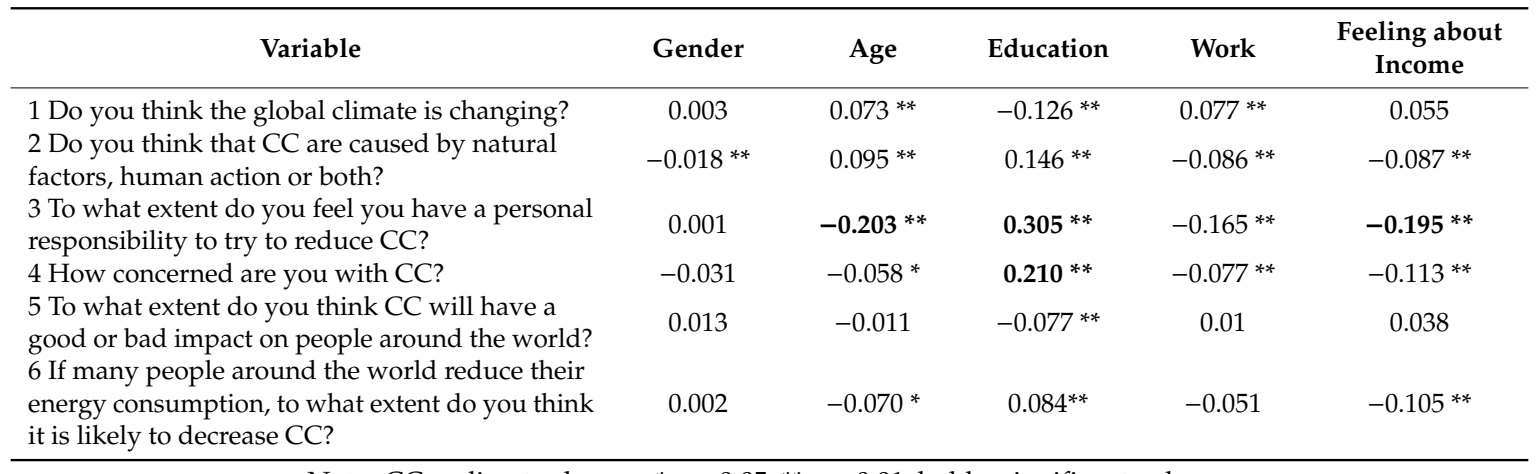

Note. $\mathrm{CC}=$ climate change. ${ }^{*} p<0.05,{ }^{* *} p<0.01$; bold-significant values.

These results mean that older respondents have less sense of personal responsibility for reducing $\mathrm{CC}$. On the other hand, respondents with less satisfaction with family income also show less sense of personal responsibility for $\mathrm{CC}$, since, on the scale of satisfaction rating with family income, the lower value responses reflect greater satisfaction with the income. Concerning education, the results mentioned above mean that the respondents with higher education report higher values of personal responsibility for CC. In the same Table 6, it is also observed that the concern with CC is significantly positively correlated, above $r=0.200$, with the number of years of education. These results indicate that respondents with higher education are more concerned with CC.

To answer to $\mathbf{H} 3$ (People with greater concern in the face of CC and who most believe in the negative effects of these changes will subscribe to higher values of self-transcendence.), it is found that, concerning motivational and second-order values, and considering the correlations above $r=0.200$, the concern with CC is negatively correlated with universalism, benevolence and self-transcendence, confirming $\mathbf{H 3}$. These results mean that the respondents who subscribe to higher values of universalism, benevolence and self-transcendence express more concern for CC. Moreover, the impacts, either positive or negative, of CC are positively correlated with universalism and self-transcendence (Table 7). These results reveal that respondents who express more negative beliefs about the impact of CC subscribe to higher values of universalism and self-transcendence.

To answer to $\mathbf{H} 4$ (education, gender and age, as well as concern about CC, explain, respectively, conservation (education and concern for CC), self-transcendence (gender and concern for CC) and openness to change (age, gender and concern with CC)), an MLR analysis was carried out, aiming to know the sociodemographic and independent variables that explain the Schwartz's second-order dimensions. Starting with conservation, it was found that the number of years of education and the concern with CC are those that significantly contribute to explaining $11.8 \%$ of the variance of the second-order dimension conservation (Table 8). In line with this, and considering the sign of the test result and the increasing or decreasing direction of the answer scale to the questions, the people with fewer years of education completed and those most concerned with CC are the most conservative, partially confirming $\boldsymbol{H} 4$. 
Table 7. Spearman Roh correlations between climate change, motivational values and second-order values.

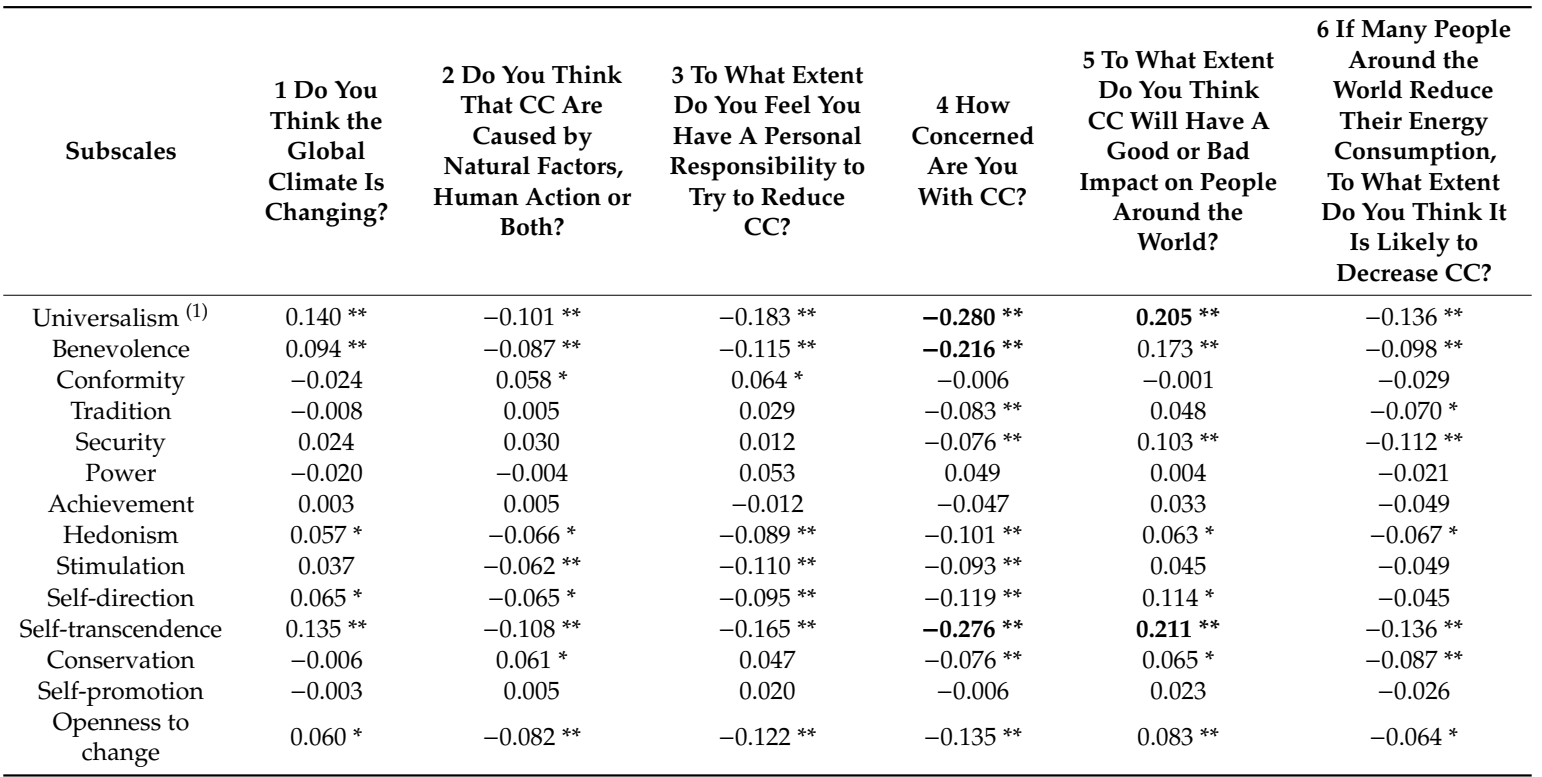

Note: ${ }^{(1)}$ coding: 1 (exactly like me) to 6 (has nothing to do with me); $C \mathrm{C}=$ climate change; ${ }^{*} p<0.05,{ }^{* *} p<0.01$; bold—significant values.

Table 8. Multiple linear regression: contribution to the explanation of the second-order dimension conservation.

\begin{tabular}{|c|c|c|c|c|c|c|c|c|c|}
\hline \multirow[b]{2}{*}{ Model } & \multirow[b]{2}{*}{$R$} & \multirow[b]{2}{*}{$R^{2}$} & \multirow[b]{2}{*}{$\begin{array}{c}\text { Adjusted } \\
R^{2}\end{array}$} & \multirow[b]{2}{*}{$\begin{array}{c}\text { Standard Error } \\
\text { of Estimate }\end{array}$} & \multicolumn{5}{|c|}{ Change Statistics } \\
\hline & & & & & $R^{2}$ & $F$ & $d f 1$ & $d f 2$ & Sig. $F$ \\
\hline 1 & 0.321 & 0.103 & 0.102 & 0.72764 & 0.103 & 138.848 & 1 & 1210 & 0.000 \\
\hline \multirow[t]{2}{*}{2} & 0.346 & 0.120 & 0.118 & 0.72117 & 0.017 & 22.781 & 1 & 1209 & 0.000 \\
\hline & & & $B$ & Error & $\beta$ & $t$ & $p$ & & \\
\hline \multirow[t]{2}{*}{1} & \multirow{2}{*}{\multicolumn{2}{|c|}{$\begin{array}{c}\text { (Constant) } \\
\text { Complete years of } \\
\text { education }\end{array}$}} & 2.445 & 0.046 & & 530.645 & 0.000 & & \\
\hline & & & 0.047 & 0.004 & 0.321 & 110.783 & 0.000 & & \\
\hline \multirow[t]{3}{*}{2} & \multirow{3}{*}{\multicolumn{2}{|c|}{$\begin{array}{c}\text { (Constant) } \\
\text { Complete years of } \\
\text { education } \\
\text { Concern about CC }\end{array}$}} & 2.796 & 0.086 & & 320.394 & 0.000 & & \\
\hline & & & 0.051 & 0.004 & 0.349 & 120.639 & 0.000 & & \\
\hline & & & -0.112 & 0.023 & -0.132 & -40.773 & 0.000 & & \\
\hline
\end{tabular}

Note. $\mathrm{CC}=$ climate change; $R=$ correlation; $R^{2} \times 100=\%$ of explained variance; $F=$ Snedecor's $F$ distribution; $d f=$ degrees of freedom; Sig = significance; $B=$ shared variance between variables; $\beta=$ regression coefficient; $t=$ Student's $t$-test; $p$-value $=$ probability; bold—significant values .

An MLR analysis to know the sociodemographic and independent variables that explain self-transcendence was subsequently performed. It was found that gender and concern for CC are the variables that significantly contribute to explaining $10.1 \%$ of the variance of the second-order dimension self-transcendence (Table 9). Thus, being a woman and being more concerned with CC explains self-transcendence, partially confirming $\mathbf{H 4}$.

To know the sociodemographic and independent variables that explain the openness to change, an MLR analysis was carried out. It was found that age, gender and concern for CC are those that significantly contribute to explaining $13 \%$ of the variance of the second-order dimension openness to change (Table 10). These observations translate that being younger, being male and having more concerns about CC explains a greater openness to change, partially confirming the $\mathbf{H} 4$. No explanatory model for Self-Promotion was found. 
Table 9. Multiple linear regression: contribution to the explanation of the second-order dimension self-transcendence.

\begin{tabular}{|c|c|c|c|c|c|c|c|c|c|}
\hline \multirow[b]{2}{*}{ Model } & \multirow[b]{2}{*}{$\boldsymbol{R}$} & \multirow[b]{2}{*}{$R^{2}$} & \multirow[b]{2}{*}{$\begin{array}{c}\text { Adjusted } \\
R^{2}\end{array}$} & \multirow[b]{2}{*}{$\begin{array}{l}\text { Standard Error } \\
\text { of Estimate }\end{array}$} & \multicolumn{5}{|c|}{ Change Statistics } \\
\hline & & & & & $R^{2}$ & $F$ & $d f 1$ & $d f 2$ & Sig. $F$ \\
\hline 1 & 0.143 & 0.020 & 0.019 & 0.67426 & 0.020 & 24.047 & 1 & 1158 & 0.000 \\
\hline \multirow[t]{2}{*}{2} & 0.322 & 0.104 & 0.101 & 0.64576 & 0.083 & 35.812 & 3 & 1155 & 0.000 \\
\hline & & & $B$ & Error & $\beta$ & $t$ & $p$ & & \\
\hline \multirow[t]{2}{*}{1} & \multirow{2}{*}{\multicolumn{2}{|c|}{$\begin{array}{l}\text { (Constant) } \\
\text { Gender }\end{array}$}} & 2.509 & 0.065 & & 38.311 & 0.000 & & \\
\hline & & & -0.196 & 0.040 & -0.143 & -4.904 & 0.000 & & \\
\hline \multirow[t]{3}{*}{2} & \multicolumn{2}{|c|}{ (Constant) } & 3.140 & 0.113 & & 27.692 & 0.000 & & \\
\hline & \multicolumn{2}{|c|}{ Gender } & -0.201 & 0.038 & -0.147 & -5.262 & 0.000 & & \\
\hline & \multicolumn{2}{|c|}{ Concern about CC } & -0.164 & 0.023 & -0.213 & -7.248 & 0.000 & & \\
\hline
\end{tabular}

Note. $C C=$ climate change; $R=$ correlation; $R^{2} \times 100=\%$ of explained variance; $F=$ Snedecor's $F$ distribution; $d f=$ degrees of freedom; Sig = significance; $B=$ shared variance between variables; $\beta=$ regression coefficient; $t=$ Student's $t$-test; $p$-value = probability; bold—significant values.

Table 10. Multiple linear regression: contribution to the explanation of the second-order dimension openness to change.

\begin{tabular}{|c|c|c|c|c|c|c|c|c|c|}
\hline \multirow[b]{2}{*}{ Model } & \multirow[b]{2}{*}{$R$} & \multirow[b]{2}{*}{$R^{2}$} & \multirow[b]{2}{*}{$\begin{array}{l}\text { Adjusted } \\
R^{2}\end{array}$} & \multirow[b]{2}{*}{$\begin{array}{l}\text { Standard Error } \\
\text { of Estimate }\end{array}$} & \multicolumn{5}{|c|}{ Change Statistics } \\
\hline & & & & & $R^{2}$ & $F$ & $d f 1$ & $d f 2$ & Sig. $F$ \\
\hline 1 & 0.348 & 0.121 & 0.119 & 0.76069 & 0.121 & 84.143 & 2 & 1224 & 0.000 \\
\hline \multirow[t]{2}{*}{2} & 0.363 & 0.132 & 0.130 & 0.75633 & 0.011 & 15.164 & 1 & 1223 & 0.000 \\
\hline & & & $B$ & Error & $\beta$ & $t$ & $p$ & & \\
\hline \multirow[t]{3}{*}{1} & \multicolumn{2}{|c|}{ (Constant) } & 2.019 & 0.095 & & 21.285 & 0.000 & & \\
\hline & \multicolumn{2}{|c|}{ Age } & 0.015 & 0.001 & 0.341 & 12.723 & 0.000 & & \\
\hline & \multicolumn{2}{|c|}{ Gender } & 0.105 & 0.044 & 0.064 & 2.394 & 0.017 & & \\
\hline \multirow[t]{4}{*}{2} & \multicolumn{2}{|c|}{ (Constant) } & 2.371 & 0.131 & & 18.149 & 0.000 & & \\
\hline & \multicolumn{2}{|c|}{ Age } & 0.015 & 0.001 & 0.333 & 12.456 & 0.000 & & \\
\hline & \multicolumn{2}{|c|}{ Gender } & 0.100 & 0.044 & 0.061 & 2.288 & 0.022 & & \\
\hline & \multicolumn{2}{|c|}{ Concern about CC } & -0.093 & 0.024 & -0.104 & -3.894 & 0.000 & & \\
\hline
\end{tabular}

Note. $C C=$ climate change; $R=$ correlation; $R^{2} \times 100=\%$ of explained variance; $F=$ Snedecor's $F$ distribution; $d f=$ degrees of freedom; Sig = significance; $B=$ shared variance between variables; $\beta=$ regression coefficient; $t=$ Student's $t$-test $;$-value $=$ probability; bold—significant values .

\section{Discussion}

This study aimed to understand the contribution of attitudes towards CC to explain Schwartz's values, i.e., how these attitudes explain the variance of the author's motivational human values, in a representative sample of the Portuguese population. A public ESS database was used, selecting the appropriate variables to the study, previously clarified in the methodology, to test four initial hypotheses.

It can be generally stated that the data of this study allow accepting as probable a large part of the alternative hypotheses initially formulated, i.e., $\mathbf{H 1}$ to $\mathbf{H 4}$. Cronbach's alpha values on the scale of values observed in the present study are lower than those found in the validation study of Granjo and Peixoto [18]. The difference may be justified by the different size and heterogeneity of the samples [53]. The hierarchy of values observed in the sample follows the same pattern. According to Schwartz [21], it has been systematically found in other representative samples from different cultures, regardless of the instrument used the following: universalism, benevolence and self-direction as more dominant and power and stimulation as less representative. As underlined by the same study, this pancultural pattern is detected, despite the idiosyncrasy of each individual or sample, and this reference structure can be used to observe which values register distinctly high or reduced priorities in a given sample.

The expression of values as a function of the sample's sociodemographic variables reveals that the older respondents are more conservative, with the more educated being less conservative and more 
open to change. Women are more conservative and self-transcending than men, who, in turn, are more open to change. These results are in line with the hypotheses raised in the present study, $\mathbf{H 1}$ to $\mathbf{H 4}$, and confirmed in the literature by Schwartz [16].

Sociodemographic variables correlate with Schwartz's values: age with conservation, self-transcendence, self-promotion and openness to change; men subscribe more than women instrumental and action values (self-promotion and openness to change), while women are more oriented than men to relational and benevolence values (self-transcendence). Education is associated with self-promotion, openness to change and conservation. Regarding the association of the variables self-transcendence and self-promotion with age, the results in the present sample do not allow to confirm the predicted $\boldsymbol{H}$ 1. Thus, self-transcendence does not prove to be higher in older participants, contrary to what has been indicated in another study by Ellermann and Reed [54]. About education, and following what was foreseen, it can be observed that with more education, the openness to change also increases in the sample, decreasing conservation. However, it is not confirmed that self-promotion is higher in the participants with higher years of education as it would be expected, according to the study by Schwartz [16].

Sociodemographic variables also correlate with variables about attitudes towards CC: education with concern for CC and personal responsibility towards them; age with personal responsibility about CC. The feeling of satisfaction to income correlates positively with personal responsibility towards CC. Because inactive respondents concerning work are more conservative, this is a finding for which it was not possible to find confirmation or contradiction in the literature. However, Reeskens and Vandecasteele [55] claim that human values are immune to economic crises, suggesting that it is not because they are unemployed that people change the way they see the world. The same authors admit that the possible feeling of insecurity and uncertainty regarding the future, resulting from the condition of unemployment, may be associated with a more conservative attitude in search of security, which may be more or less temporary. This explanation may constitute a theme for a more oriented and in-depth investigation on the subject under analysis.

Regarding attitudes towards CC, older participants and those whose satisfaction with their income is reduced show less sense of personal responsibility to reduce CC. As older people are more conservative and less open to change, this result was expected, and it is in line with what was also observed in the study by Poortinga and colleagues [8]. People dissatisfied with their income may feel less responsible for reducing CC, as they adopt a more conservative attitude and are less open to change, as the results show. This finding seems relevant to the planning of interventions aimed at mitigating CC since it allows the identification of two groups of subjects possibly less involved in the necessary changes. These subjects may be mobilized through messages designed to increase their feeling of power and self-efficacy. Chan [44] also points out that human values, on average, have only a small effect on pro-environmental behavior, and social and situational factors are also considered by individuals.

The hypothesis that people with greater concern towards CC and who most believe in its negative effects subscribe to higher values of self-transcendence, $\mathbf{H} 3$, was also confirmed. Finally, it was anticipated that education, gender and age, as well as concern for CC, explain, respectively, conservation (education and concern for CC), self-transcendence (gender and concern for CC) and openness to change (age, gender and concern for CC).

As highlighted in the theoretical component of the present study, self-transcendence is the second-order value that most consistently appears in the literature as a predictor of behaviors aimed at mitigating CC [14]. In the present study, women, those who believe most in the negative effects of CC and those most concerned with CC, are the ones who reveal the greatest self-transcendence. Although indirectly, it is expected that this set of participants tends to become more involved in environmentally responsible behaviors, as shown in the study by Howell [24].

The concern with CC is an explanatory element, although of reduced strength, for the values of second-order: self-transcendence, conservation and openness to change. The concern with CC seems 
to be an engine for action through its expression in the values that people subscribe to. However, it is noted that the contribution is similar for essentially opposite values such as conservation and openness to change. Although the concern with CC appears in this study as an explanatory variable for motivational human values, in association with some sociodemographic variables, the reduced strength of the contribution leaves space for other explanations. Another line of research focused on more positive dimensions of CC underlines that the concern with CC and the environment should not be the message used to promote environmentally responsible behavior [56]. Thus, research suggests that the catalysts for change may be social justice, community, frugality, personal integrity, health and self-efficacy beliefs [24,57] and how messages reflect cultural values [13].

Self-promotion does not show any correlation with attitudes towards CC. This observation is in line with the findings of the investigation carried out by Corner and colleagues [13], which points to Self-Promotion as the dimension of second-order values that in a less congruent and consistent way appears associated with positive long-term involvement with pro-behavior environmental issues. Noting that the values of benevolence and self-transcendence (social focus) predominate in the sample over values of power, hedonism and self-promotion (personal focus), it can be anticipated the possibility that messages highlighting social or community benefits of pro-environmental behaviors may contribute to greater involvement in this type of actions, as also anticipated by some studies $[24,38,43]$.

Communication with a heterogeneous audience should be done in a holistic and integrative way. Ballantyne (2016) states that the traditional functionalist communication paradigm, which considers communication as the passage of information from the sender to the receiver, is still the most used in the context of climate issues. The same author highlights the need to change to the constructivist model of communication, coauthoring meaning, in which the socio-cultural context is also recognized as an influencing factor [58].

Understanding the weak contribution of the concern with CC for the explanation of second-order values and considering this contribution both for openness to change (more favorable to the adoption of pro-environmental behaviors) and for conservation (less favorable to the adoption of pro-environmental behaviors), it is suggested the continuation of the study for better clarification of the contribution of attitudes towards CC for the explanation of human values. It seems to be expected that the valorization of the habitat, an essential condition for human life, will be reflected in human motivational values in a more evident way. The change in values eventually observed over time may constitute an indicator of the relevant social transformations that may occur in response to extreme events, as underlined by Davidov and colleagues [59], and CC may constitute one of these transformational factors.

\section{Conclusions}

CC represents a global challenge for humanity, and the impact of anthropogenic actions is an unequivocal contribution to the environmental issue's aggravation. Human values are recognized as psychological constructs that guide people in their attitudes and actions in different areas of life, and the promotion of pro-environmental behaviors must be considered a priority. The present work aimed to understand the contribution of attitudes towards CC and selected sociodemographic variables to explain Schwartz's motivational human values. For this, the Portuguese sample of the ESS (2016), round 8, was used. Among the attitudes towards CC, only the concern with CC seems to contribute, although of little significance, to the explanation of Schwartz's second-order human values: self-transcendence, conservation and openness to change. Therefore, the research question "Do attitudes towards climate change significantly contribute to explaining Schwartz's values?" has not been answered positively. This may be explained considering that human values are resistant to more contextual aspects. Although the values of regressions are not very high, they are important since human values structure changes throughout the individual confrontation with reality. Understanding beliefs and attitudes towards CC, and their relation with motivational human values, must be recognized as a pathway to more precise and effective public policy design aimed at changing habits and increasing environmental awareness investment. The fight against CC is a battle 
of the present, and only in the future will it be possible to know if humanity won. The human values explored in this text significantly contribute to care about the future of the next generations.

\section{Limitations}

The limitations of this study are mainly due to the fact that attitudes towards CC are assessed by a set of questions that do not constitute a scale or a single factor. Future research should seek to develop an instrument that allows a more rigorous assessment of attitudes towards CC and to better clarification of the findings in this study. Alongside, it would be important to explore these results in distinct samples. It is suggested the continuation of the study for better clarification of the contribution of attitudes towards CC for the explanation of human values.

Author Contributions: Conceptualization, N.M.O.C.D.; data curation, N.M.O.C.D. and Â.L.; formal analysis, N.M.O.C.D., D.G.V., M.A.P.D. and Â.L.; investigation, N.M.O.C.D. and D.G.V.; methodology, N.M.O.C.D.; project administration, Â.L.; software, N.M.O.C.D. and Â.L.; supervision, Â.L.; validation, M.A.P.D. and Â.L.; visualization, H.F.P.e.S., M.A.P.D. and Â.L.; writing—original draft, N.M.O.C.D. and Â.L.; writing-review and editing, D.G.V., H.F.P.e.S., M.A.P.D and Â.L. All authors have read and agreed to the published version of the manuscript.

Funding: This research received no external funding.

Conflicts of Interest: The authors declare no conflict of interest.

\section{References}

1. UNFPA. State of World Population 2020; UNFPA: New York, NY, USA, 2020.

2. Swim, J.K.; Clayton, S.; Howard, G.S. Human behavioral contributions to climate change: Psychological and contextual drivers. Am. Psychol. 2011, 66, 251-264. [CrossRef] [PubMed]

3. Oliveira, G.M.; Vidal, D.G.; Ferraz, M.P. Urban Lifestyles and Consumption Patterns. In Sustainable Cities and Communities. Encyclopedia of the UN Sustainable Development Goals; Filho, W.L., Azul, A.M., Brandli, L., Özuyar, P.G., Wall, T., Eds.; Springer Nature Switzerland AG: Cham, Switzerland, 2019; pp. 1-10. ISBN 978-3-319-71061-7.

4. Steffen, W.; Persson, A.; Deutsch, L.; Zalasiewicz, J.; Williams, M.; Richardson, K.; Crumley, C.; Crutzen, P.; Folke, C.; Gordon, L.; et al. The anthropocene: From global change to planetary stewardship. Ambio 2011, 40, 739-761. [CrossRef] [PubMed]

5. IPCC. AR5 Synthesis Report: Climate Change 2014; IPCC: Geneva, Switzerland, 2014.

6. United Nations. Transforming Our World: The 2030 Agenda for Sustainable Development. Resolution Adopted by the General Assembly on 25 September 2015, A/RES/70/1; United Nations: Geneva, Switzerland, 2015.

7. WHO. World Health Organization (WHO). Climate Change; WHO: Geneva, Switzerland, 2020.

8. Poortinga, W.; Whitmarsh, L.; Steg, L.; Böhm, G.; Fisher, S. Climate change perceptions and their individual-level determinants: A cross-European analysis. Glob. Environ. Chang. 2019, 55, 25-35. [CrossRef]

9. Seixas, P.C.; Dias, R.C.; Vidal, D.G. Escala de Identidade Ambientalista: Uma ferramenta para descobrirmos que ambientalistas somos [Environmentalist identity scale: A tool to discover which environmentalists we are]. Sociol. Rev. da Fac. Let. da Univ. do Porto 2020, 39, 56-83. [CrossRef]

10. Rocheach, M. The Nature of Human Values; Free Pr: New York, NY, USA, 1973.

11. Schwartz, S.H. Universals in the content and structure of values: Theoretical advances and empirical tests in 20 countries. Adv. Exp. Soc. Psychol. 1992, 25, 1-65.

12. van der Linden, $\mathrm{S}$. The social-psychological determinants of climate change risk perceptions: Towards a comprehensive model. J. Environ. Psychol. 2015, 41, 112-124. [CrossRef]

13. Corner, A.; Markowitz, E.; Pidgeon, N. Public engagement with climate change: The role of human values. WIREs Clim. Chang. 2014, 5, 411-422. [CrossRef]

14. Steg, L.; Vlek, C. Encouraging pro-environmental behaviour: An integrative review and research agenda. J. Environ. Psychol. 2009, 29, 309-317. [CrossRef]

15. Prati, G.; Pietrantoni, L.; Albanesi, C. Human values and beliefs and concern about climate change: A Bayesian longitudinal analysis. Qual. Quant. 2018, 52, 1613-1625. [CrossRef] 
16. Schwartz, S.H. A proposal for measuring value orientations across nations. In Questionnaire Development Package of the European Social Survey; European Social Survey: London, UK, 2003; pp. 259-319. ISBN 047166782X.

17. Schwartz, S.H. Basic human values: Theory, methods, and applications. Jerusalem Hebr. Univ. 2006, 48, 49-71. [CrossRef]

18. Granjo, M.; Peixoto, F. Contributo para o estudo da Escala de Valores Humanos de Schwartz em professores [Contribution to the study of schwartz's Human Values Scale in teachers.]. Laboratório Psicol. 2013, 11. [CrossRef]

19. Inglehart, R.F. Changing Values among Western Publics from 1970 to 2006. West Eur. Polit. 2008, 31, 130-146. [CrossRef]

20. Prati, G.; Zani, B. The Effect of the Fukushima Nuclear Accident on Risk Perception, Antinuclear Behavioral Intentions, Attitude, Trust, Environmental Beliefs, and Values. Environ. Behav. 2012, 45, 782-798. [CrossRef]

21. Schwartz, S.H. An overview of the Schwartz theory of basic values. Psychol. Cult. Artic. 2012, 11, 12-13. [CrossRef]

22. Schwartz, S.H.; Boehnke, K. Evaluating the structure of human values with confirmatory factor analysis. J. Res. Pers. 2004, 38, 230-255. [CrossRef]

23. Prince-Gibson, E.; Schwartz, S.H. Value Priorities and Gender. Soc. Psychol. Q. 1998, 61, 49-67. [CrossRef]

24. Howell, R.A. It's not (just) "the environment, stupid!" Values, motivations, and routes to engagement of people adopting lower-carbon lifestyles. Glob. Environ. Chang. 2013, 23, 281-290. [CrossRef]

25. Katz-Gerro, T.; Greenspan, I.; Handy, F.; Lee, H.Y. The relationship between Value Types and Environmental Behaviour in Four Countries: Universalism, Benevolence, Conformity and Biospheric Values Revisited. Environ. Values 2017, 26, 223-249. [CrossRef]

26. O'Brien, K.L.; Wolf, J. A values-based approach to vulnerability and adaptation to climate change. WIREs Clim. Chang. 2010, 1, 232-242. [CrossRef]

27. Bouman, T.; Steg, L.; Kiers, H.A.L. Measuring Values in Environmental Research: A Test of an Environmental Portrait Value Questionnaire. Front. Psychol. 2018, 9, 564. [CrossRef]

28. IPCC. The Intergovernmental Panel on Climate Change. Available online: https://www.ipcc.ch/sr15/(accessed on 21 September 2020).

29. UNFCCC. Introduction to Science; UNFCCC: New York, NY, USA, 2020.

30. Marshall, N.A.; Thiault, L.; Beeden, A.; Beeden, R.; Benham, C.; Curnock, M.I.; Diedrich, A.; Gurney, G.; Jones, L.; Marshall, P.A. Our environmental value orientations influence how we respond to climate change. Front. Psychol. 2019, 10, 1-8. [CrossRef] [PubMed]

31. Wang, J.; Kim, S. Analysis of the impact of values and perception on climate change skepticism and its implication for public policy. Climate 2018, 6, 99. [CrossRef]

32. Santos, F.D. Alterações Globais: Os Desafios e os Riscos Presentes e Futuros [Global Changes: Present and Future Challenges and Risks]; Fundação Francisco Manuel dos Santos: Lisboa, Portugal, 2012.

33. Pauleit, S.; Zölch, T.; Hansen, R.; Randrup, T.B.; Konijnendijk van den Bosch, C. Nature-Based Solutions and Climate Change_-Four Shades of Green; Springer: Cham, Switzerland, 2017; ISBN 978-3-319-56091-5.

34. Zemp, M.; Frey, H.; Gärtner-Roer, I.; Nussbaumer, S.U.; Hoelzle, M.; Paul, F.; Haeberli, W.; Denzinger, F.; Ahlstrøm, A.P.; Anderson, B.; et al. Historically unprecedented global glacier decline in the early 21st century. J. Glaciol. 2015, 61, 745-762. [CrossRef]

35. Vargo, L.J.; Anderson, B.M.; Dadić, R.; Horgan, H.J.; Mackintosh, A.N.; King, A.D.; Lorrey, A.M. Anthropogenic warming forces extreme annual glacier mass loss. Nat. Clim. Chang. 2020, 10, 856-861. [CrossRef]

36. Watts, N.; Adger, W.N.; Ayeb-Karlsson, S.; Bai, Y.; Byass, P.; Campbell-Lendrum, D.; Colbourn, T.; Cox, P.; Davies, M.; Depledge, M.; et al. The Lancet Countdown: Tracking progress on health and climate change. Lancet 2017, 389, 1151-1164. [CrossRef]

37. Nilsson, A.; von Borgstede, C.; Biel, A. Willingness to accept climate change strategies: The effect of values and norms. J. Environ. Psychol. 2004, 24, 267-277. [CrossRef]

38. Howell, R.A.; Allen, S. Significant life experiences, motivations and values of climate change educators. Environ. Educ. Res. 2016, 1-19. [CrossRef]

39. de Groot, J.I.M.; Steg, L. Value Orientations to Explain Beliefs Related to Environmental Significant Behavior: How to Measure Egoistic, Altruistic, and Biospheric Value Orientations. Environ. Behav. 2007, 40, 330-354. [CrossRef]

40. Slimak, M.W.; Dietz, T. Personal Values, Beliefs, and Ecological Risk Perception. Risk Anal. 2006, 26, 1689-1705. [CrossRef] 
41. Stern, P.C. New Environmental Theories: Toward a Coherent Theory of Environmentally Significant Behavior. J. Soc. Issues 2000, 56, 407-424. [CrossRef]

42. Hornsey, M.J.; Harris, E.A.; Bain, P.G.; Fielding, K.S. Meta-analyses of the determinants and outcomes of belief in climate change. Nat. Clim. Chang. 2016, 6, 622-626. [CrossRef]

43. Howell, R.A.; Allen, S. People and planet: Values, motivations and formative influences of individuals acting to mitigate climate change. Environ. Values 2017, 26, 131-155. [CrossRef]

44. Chan, H.W. When do values promote pro-environmental behaviors? Multilevel evidence on the self-expression hypothesis. J. Environ. Psychol. 2019, 101361. [CrossRef]

45. Sloot, D.; Kutlaca, M.; Medugorac, V.; Carman, P. Recycling alone or protesting together? Values as a basis for pro-environmental social change actions. Front. Psychol. 2018, 9, 1-10. [CrossRef] [PubMed]

46. Adger, W.N.; Barnett, J.; Brown, K.; Marshall, N.; O’Brien, K. Cultural dimensions of climate change impacts and adaptation. Nat. Clim. Chang. 2013, 3, 112-117. [CrossRef]

47. ESS. European Social Survey_ESS; European Social Survey: London, UK, 2020.

48. European Social Survey 8: European Social Survey Round 8 Data. In Data File Edition 2. 1. NSD-Norwegian Centre for Research Data, Norway-Data Archive and Distributor of ESS Data for ESS ERIC. European Commission (2019):'Eurobarometer Interactive'; NSD-ESS8-2016; European Social Survey: London, UK, 2016.

49. Schwartz, S.H. Studying values: Personal beginnings, future directions. J. Cross. Cult. Psychol. 2011, 42, 307-319. [CrossRef]

50. Armstrong, A.K.; Krasny, M.E.; Schuldt, J.P. Climate Change Attitudes and Knowledge. In Communicating Climate Change: A Guide for Educators; Armstrong, A.K., Krasny, M.E., Schuldt, J.P., Eds.; Cornell University Press, Comstock Publishing Associates: London, UK, 2018; pp. 21-24.

51. Smith, T.W.; Kim, J.; Son, J. Public Attitudes toward Climate Change and Other Environmental Issues across Countries. Int. J. Sociol. 2017, 47, 62-80. [CrossRef]

52. Marôco, J. Análise de Equações Estruturais: Fundamentos teóricos, software \& Aplicações [Structural Equation Analysis: Theoretical Foundations, Software \& Applications]; Report Number, Lda: Pêro Pinheiro, Portugal, 2010.

53. Chilton, P.; Crompton, T.; Kasser, T.; Maio, G.R.; Nolan, A. Communicating Bigger-than-Self Problems to Extrinsically-Oriented; Values and Frames: Surrey, UK, 2012.

54. Ellermann, C.R.; Reed, P.G. Self-transcendence and depression in middle-age adults. West. J. Nurs. Res. 2001, 23, 698-713. [CrossRef]

55. Reeskens, T.; Vandecasteele, L. Hard times and European youth. The effect of economic insecurity on human values, social attitudes and well-being. Int. J. Psychol. 2017, 52, 19-27. [CrossRef]

56. Cook, S.; Ma, Z. The interconnectedness between landownner knouledge, value, belief, attitude, and willingness to act: Political implications for carbon sequestration on private rangelands. J. Environ. Manag. 2014, 90-99. [CrossRef]

57. Bostrom, A.; Böhm, G.; O'Connor, R.E. Targeting and tailoring climate change communications. WIREs Clim. Chang. 2013, 4, 447-455. [CrossRef]

58. Ballantyne, A.G. Climate change communication: What can we learn from communication theory? WIREs Clim. Chang. 2016, 7, 329-344. [CrossRef]

59. Davidov, E.; Schmidt, P.; Schwartz, S.H. Bringing values back in: The adequacy of the European Social Survey to measure values in 20 countries. Public Opin. Q. 2008, 72, 420-445. [CrossRef]

Publisher's Note: MDPI stays neutral with regard to jurisdictional claims in published maps and institutional affiliations.

(C) 2020 by the authors. Licensee MDPI, Basel, Switzerland. This article is an open access article distributed under the terms and conditions of the Creative Commons Attribution (CC BY) license (http://creativecommons.org/licenses/by/4.0/). 